\title{
PREDATORY BEHAVIOR OF THE XANTHID CRAB ERIPHIA SMITHII BREAKING THE SHELLS CONTAINING HERMIT CRABS
}

With 1 Table and 3 Text-figres

Seiichi Watanabe and Kenyo Murata

(Department of Aquatic Bioscience and Mariculture, Tokyo University of Fisheries*)

イボイワオウギガニのヤドカリ類に対する捕食行動

表 1 , 図 3

渡邊精一・村田憲要

（東京水産大学水産生物資源学研究室）

\begin{abstract}
The Xanthid crab Eriphia smithii preys on hermit crabs. Two chelae, ambulatory legs, and mouth parts are used for capturing them. The crab breaks shells with hermit crabs in them by using its massive and powerful master claw. About $70 \%$ of the crabs are right-handed. Many species of shells occupied by hermit crabs are found at Banda Shore. E. smithii breaks these shells.
\end{abstract}

\section{Introduction}

Many crabs, such as Calappa flamea (HerbSt) (Shoup, 1968), C. gallus capellonis LAurie (TAKeda and Suga, 1979), Calpilius maculatus (Linnaeus), C. convexus (Forscal) (Vermeij, 1976), Eriphia squamata Stimpson, Ozius verreauxii Saussure (Bertness and Cunningham, 1981), prey on gastropods or hermit crabs. The Xanthid crab Eriphia smithii MACLEAY, an Indo West-Pacific species distributing in the temperate to the tropical zone, inhabits the intertidal zone of the rocky shore and preys on the seasnailes and hermit crabs. In this article, the predatory behavior of E. smithii observed in the laboratory.

\footnotetext{
* Konan, Minato-ku, Tokyo 108, Japan
} 


\section{Materials and Methods}

The crabs ranging from 21.7 to $34.3 \mathrm{~mm}$ in carapace length are collected at the rocky shore near the Banda Marine Station of Tokyo University of Fisheries in Chiba Prefecture. They are reared in the cycling sea water aquaria in the laboratory and are fed with shells containing hermit crabs, Pagrus geminus and Clibanarius virrescens.

\section{Results}

Morphology of the Crab

Eriphia smithii has a master and a minor claw. The massive master claw (crusher)

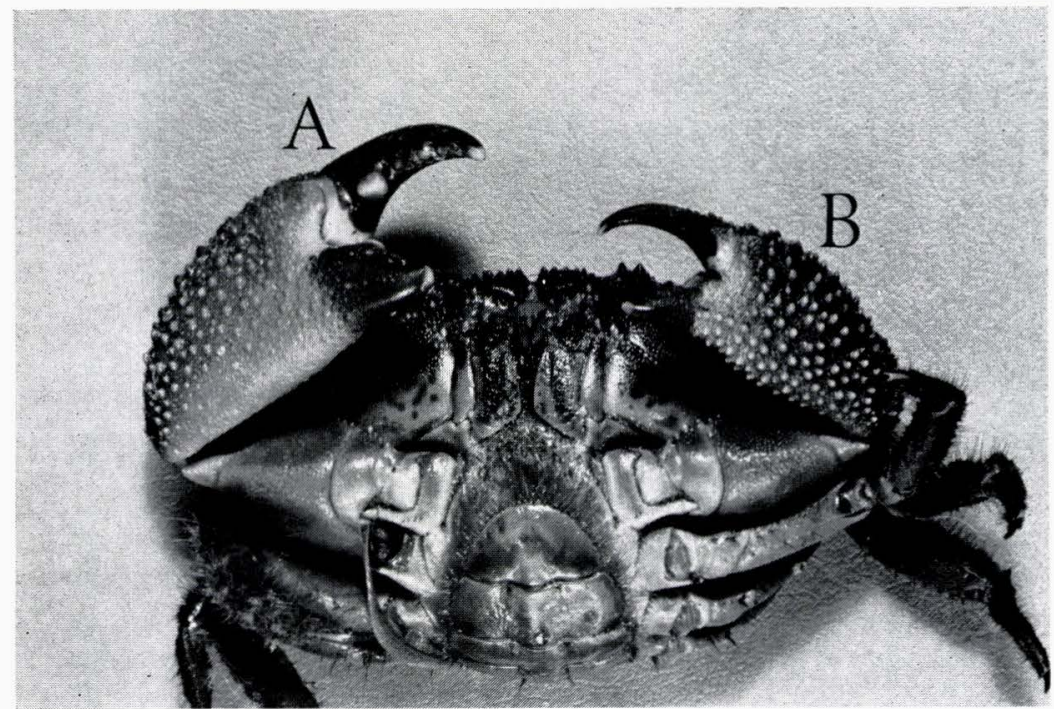

Fig. 1. Eriphia smithii with master (A) and minor (B) claws in ventral view.

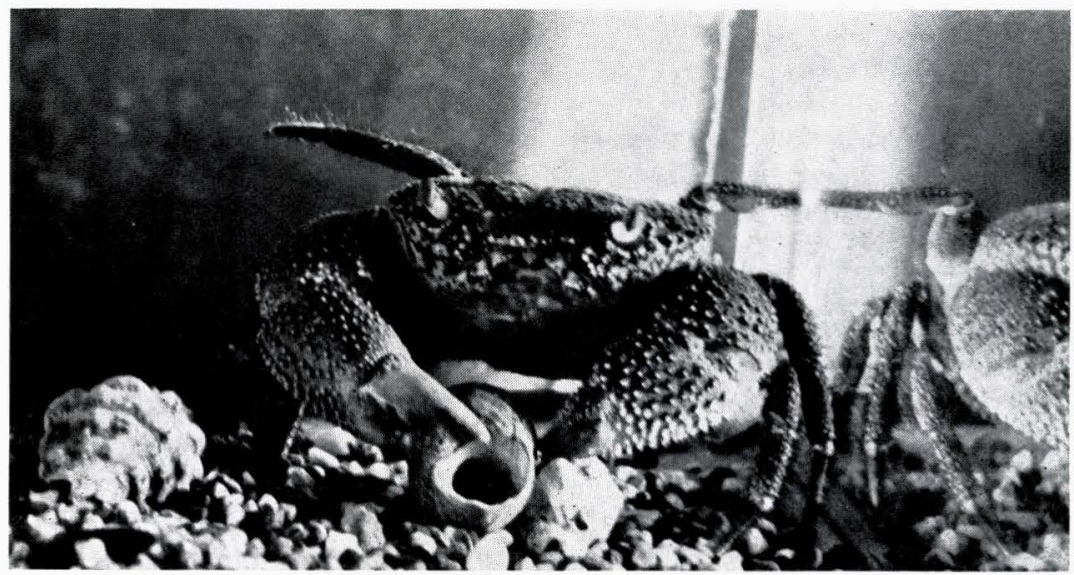

Fig. 2. Eriphia smithii which is breaking the shell Turbo multiformis containing the hermit crab. 
(Fig. 1) is strong and is utilized to crush or break shells. The minor one (nipper) (Fig. 1) is relatively slender and is employed for taking food. The crabs with right master claw account for about $70 \%$ of the specimens collected at Banda Shore.

\section{Predatory Behavior}

Upon finding a shell occupied by a hermit crab, E. smithii holds the shell by using two chelae, ambulatory legs and mouth parts. The crab inserts its dactil into the shell and rolls the shell by using its chelae and ambulatory legs. After repeating this act of inserting and rolling several times or more, the crab puts its master claw into the aperture and breaks the edge or the middle part of the shell (Fig. 2). When the chela reaches the body of the hermit crab, the crab nips it with the minor claw and pulls out a part or the whole of the prey and eats it. In many cases, claws and ambulatory legs of hermit crabs are eaten at first.

Sometimes, the hermit crab trys to run away from the shell which is holded by the crab. The action of the crab is so rapid that the hermit crab has scarcely any

Table 1. The main shells which are occupied by hermit crabs in Banda Shore.

\begin{tabular}{|c|c|}
\hline Family & species \\
\hline Trochidae & $\begin{array}{l}\text { Tristichotrochus unicum (DUNKER) } \\
\text { Monodonta labio (LINNE) } \\
\text { Chlorostoma lischkei (TAPPARONE-CANEFRI) } \\
\text { Omphalius pheifferi (PHILIPPI) } \\
\text { Umbonium (Suchium) moniliferum (LAMARCK) }\end{array}$ \\
\hline Turbinidae & $\begin{array}{l}\text { Lunella coronata coreensis (RECLUZ) } \\
\text { Turbo (Marmarostoma) stenogyrus (FISCHER) }\end{array}$ \\
\hline Neritidae & Theliostyla albicilla (LINNE) \\
\hline Potamididae & Batillaria cumingii (CROssE) \\
\hline Cypraeidae & Purpuradusta gracilis japonicus (ScHILDER) \\
\hline Muricidae & $\begin{array}{l}\text { Thais spp. } \\
\text { Ergalatax contractus (REEve) }\end{array}$ \\
\hline Buccinidae & $\begin{array}{l}\text { Pisania (Japeuthria) ferrea (REEve) } \\
\text { Babyronia japonica (REEve) } \\
\text { Pollia mollis (Gould) }\end{array}$ \\
\hline Pyrenidae & $\begin{array}{l}\text { Pyrene (Sundamitrella) impolita (SOWERBY) } \\
\text { Pyrene testudinaria tylerae (GRIFFITH et PIDGEON) } \\
\text { Pyrene punctata (BURGUIERE) }\end{array}$ \\
\hline Nassariidae & $\begin{array}{l}\text { Reticunassa hiradoensis (PILSBRY) } \\
\text { Alectrion sufflatus (Gould) }\end{array}$ \\
\hline
\end{tabular}




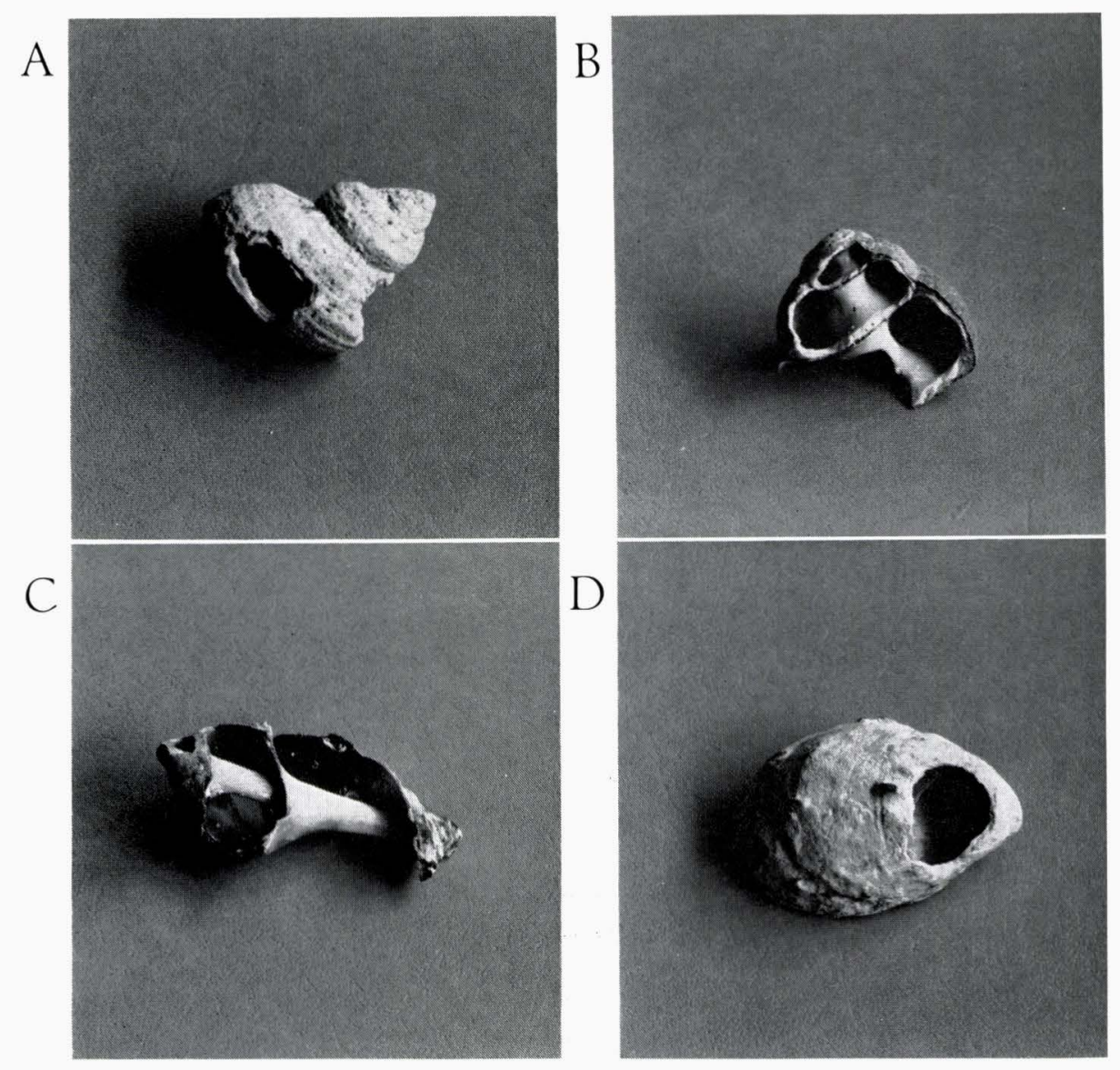

Fig. 3. The shells broken by Eriphia smithii. A: Turbo stenogyrus B: Chlorostoma lischkei C: Thais clavigera D: Theliostyla albicilla.

chance to escape.

Broken Shell Species and Predatory Mark

Shells containing hermit crabs belong to many families as in Table 1 . The predatory marks are shown in Fig. 3. The typical predatory mark is observed in Turbinids as in Fig. 3A, in which the aperture is broken and middle part of the shell is broken. In Trochids, the halft part of the shell is broken (Fig. 3B), and sometimes, the shell is crushed into pieces. E. smithii is unable to break large shells.

\section{Discussion}

Eriphia smithii shows the same behavior of capturing hermit crabs as in Calappa (Shoup, 1968; Takeda and Suga, 1979) and Daldorfia (Zipser and Vermeij). Calappa is most specialized in morphological adaptations for opening molluscan shells, while 
E. smithii breaks shells by its massive and powerful master claw. E. smithii is one of the Eriphia species bearing great chelae (VERMEIJ, 1977), and is almost right-handed, breaking many species of shells inhabit rocky shores of the temperate zone. The crab preys on shells occupied with hermit crabs in natural environment although it is scarcely observed to break shells in the field. The way of breaking shells by left-handed crabs is almost the same as that of right-handed ones, but it is not known which hand works more efficiently in getting food.

\section{References}

Bertness, M.D. and C. Cunningham, 1981. Crab shell-crushing predation and gastropod architectural defense. J. Exp. Mar. Biol. Ecol. 50: 213-230.

SHoup, J. B. 1968. Shell opening by crabs of the genus Calappa. Science 160: 887-888.

TAKEDA, M. and H. SugA, 1979. Feeding habits of box crabs, Calappa. Res. Crustacea 9: 43-46.

VermeiJ, G. J. 1976. Interoceanic differences in vulnerability of shelled prey to crab predation. Nature 260: 135-136.

VermeiJ, G. J. 1977. Patterns in crab claw size: The geography of crushing. Syst. Zool. 26: 138-151.

Zipser, E. and G. J. Vermeij, 1978. Crushing behavior of tropical and temperate crabs. J. Exp. Mar. Biol. Ecol. 31: 155-172.

要 約

イボイワオウギガニは, 貝類, ヤドカリ類を捕食する。餌を発見すると鈿脚, 歩脚, および 口部を用いて囲うように慨を抱光込む。大鉗脚（坂田地先では，約 70\%が右鉗脚が大きい）で 貝の殼口を割るか，螺層部に穴をあけ，中に棲むヤドカりを捕食する。実験に用いだドカリ は,イソヨコバサミとホンヤドカリであり，多くの貝の種を宿貝としている。貝殼の割られ方 には特徴がある。 